DOI https://doi.org/10.30525/978-9934-26-074-2-82

\title{
ПРОБЛЕМИ РЕАЛІЗАЦІЇ МІГРАЦІЙНОЇ ПОЛІТИКИ: УКРАЇНСЬКІ РЕАЛІЇ ТА ЗАСТОСУВАННЯ ДОСВІДУ ЄВРОПЕЙСЬКОГО СОЮЗУ ДО ЇХ ВИРІШЕННЯ
}

\author{
Ястремська Н. М. \\ кандидат економічних наук, \\ дочент кафедри державно-правових дисичилін \\ Донецького юридичного інституту \\ Міністерства внутрішніх справ Украӥни \\ м. Кривий Ріг, Дніпропетровська область, Україна
}

Міграційні процеси мають динамічний характер і в сучасних реаліях світового розвитку потребують значної уваги, постійного їх дослідження, аналізу та розв'язання ряду проблем, пов'язаних з цим процесом.

Значна роль міграції в житті суспільства та держави полягає в ії впливі на зовнішню і внутрішню політику, економічну і політичну стабільність та соціальну захищеність населення. Розробка ефективної міграційної політики, зводиться до вибору певних норм права, що мають врегулювати міграційні процеси і повинні стати частиною внутрішньої і зовнішньої політики держави, сприяти іiї соціально-економічному розвитку, національній безпеці, територіальній цілісності та захисту прав людей [1].

Однією з умов становлення правової держави на сучасному етапі $€$ визначення напрямів іiі міграційної політики, вдосконалення системи державного управління міграційними процесами відповідно до європейських та міжнародних стандартів у сфері реалізації прав людини. Конституцією України затверджено основні положення та норми щодо міграційної політики України, спрямованої на: впорядкування міграційних потоків, усунення несприятливих, невпорядкованих і неконтрольованих проявів та процесів міграції; гарантування та реалізацію прав мігрантів, їх політичної, юридичної, соціально-економічної та культурної інтеграції в національне середовище проживання, забезпечення прав і свобод людини та громадянина та ін. [2].

Фундаментом нормативно-правової бази міграційної політики України виступають: міжнародні угоди України: Конвенція про захист прав людини та основних свобод, Конвенція про статус біженця 1951 року та Протоколу 1967 року (2002) [3] , Декларація про державний суверенітет; закони України та нормативно-правові акти: «Про правовий статус іноземців та осіб без громадянства», «Про біженців та осіб, які 312 
потребують додаткового або тимчасового захисту», «Про імміграцію», «Про громадянство України» (2001), «Про Державну прикордонну службу України» (2003), «Про Концепцію державної міграційної політики» (2011), «Про затвердження плану заходів на 2018-2021 роки щодо реалізації Стратегії державної міграційної політики України на період до 2025 року» (2018), «Про затвердження Положення про Державну міграційну службу України» (2014), «Про схвалення Стратегії інтегрованого управління кордонами на період до 2025 року» (2019), розпорядження «Про затвердження плану заходів щодо реалізації Концепції інтегрованого управління кордонами» (2011) та ін.

Між тим, попри широкий перелік нормативно-правових документів, низка питань дотепер залишається відкритою. Реалізація міграційної політики України, передусім передбачає вирішення наступних першочергових проблем, пов'язаних 3: недосконалою нормативно-правовою базою; тривалою політичною кризою в суспільстві; спадом економіки; фрагментарністю української міграційна політики, відсутністю комплексності і системності міграційних проблем; відсутністю комплексної, узагальненої, достовірної інформації щодо всіх видів міграційних процесів, їх тенденцій та наслідків; недосконалістю напрямів оптимізації міграційної політики; не завершеністю формування цілісної системи державного регулювання трудової міграції в Україні (влади та громадських організацій); незабезпечення умов для реалізації можливостей своїх економічно активних громадян (відтік молоді, працездатного населення, низький рівень оплати праці в порівнянні з країнами $(\mathrm{C})$; недостатня робота $з$ іноземцями щодо навчання і подальшої роботи в Україні; військовий конфлікт; суттєвим дефіцитом фінансових ресурсів, необхідних для вирішення численних міграційних проблем; неврегульованість міграційних питань, що потребує укладання двосторонніх або багатобічних міжнародних договорів і угод тощо $[1,4,5]$.

Зважаючи на це українська міграційна політика потребує суттєвих перетворень та подальшої адаптації у відповідності до європейських стандартів та визнаних міжнародних механізмів регулювання міграційних процесів у рамках реалізації стратегії євроінтеграції України [1,5]:

Аналіз і врахування загальносвітових та європейських міграційних тенденцій $є$ одним із важливих чинників формування власної міграційної політики української держави. Сьогодні, за геополітичним становищем Україна знаходиться на перетині різносторонніх і різнопланових масових міграційних потоків, наша держава гостро потребує вивчення досвіду Європейського Союзу у врегулюванні міграційних процесів, розробки та вдосконалення власного, відповідного міжнародним стандартам, міграційного законодавства. 
International scientific and practical conference

Стандарти Європейського Союзу в регулюванні міграційних процесів

\begin{tabular}{|c|c|}
\hline & $\begin{array}{l}\text { Орієнтація міграційної політики й правових норм країн ЄС на використання } \\
\text { системного підходу; внбудовується в рамках дотримання прав люднни на право } \\
\text { вільного пересування }\end{array}$ \\
\hline & $\begin{array}{l}\text { Розробка концепції державної політнки в сфері інтелектуальної міграції - курс на } \\
\text { розшнрення міжнародного співробітництва, кооперація з науково-дослідннцькнми } \\
\text { фондами розвинених країн }\end{array}$ \\
\hline & $\begin{array}{l}\text { Людськнй капітал здобуває особливу значимість, іммігранти стають одним } \\
\text { важливнх факторів зростання й успіхів у конкурентній боротьбі, відбувається } \\
\text { перехід від політики обмеження до політики гнучкого керування міграційннми } \\
\text { процесамн }\end{array}$ \\
\hline & $\begin{array}{l}\text { Розвиток співробітннцтва } 3 \text { третімн країнами: інвестицій в окремі галузі } \\
\text { економіки, підтрнмка виробннцтва, створеного колишніми іммігрантамн, угод про } \\
\text { трудовий найм тощо }\end{array}$ \\
\hline & $\begin{array}{l}\text { Інтеграція розглядається як двосторонній процес. } 3 \text { одного боку, допомога } \\
\text { трудовим мігрантам, біженцям і особам за програмами возз'єднання родин зі } \\
\text { сторони країни-репіцієнта| } 3 \text { іншого - іммігранти повинні прагнути інтегруватися } \\
\text { в нове суспільство, поважати його традиціі й культуру }\end{array}$ \\
\hline & $\begin{array}{l}\text { Політика залучення кваліфікованих фахівців стає усе більше вибірковою - } \\
\text { підвищений попит на внсокий рівень освіти (полегшення іноземним фахівцям } \\
\text { доступ на національні рннкн праці, однак для середньоі та низької кваліфікації } \\
\text { залншається досить жорстокнм) }\end{array}$ \\
\hline$\rightarrow$ & $\begin{array}{l}\text { Розвиток навчальної міграції - прнносить іноземні інвестиції в національну } \\
\text { систему освіти, за рахунок висококваліфікованих кадрів, що вже пройшли } \\
\text { адаптацію в країні навчання }\end{array}$ \\
\hline & $\begin{array}{l}\text { Політнка в сфері імміграції заснована на розумінні необхідності залучення країн } \\
\text { до міжнародного рннку праці, підготовка та укладання двосторонніх угод по } \\
\text { міжнародному трудовому обміну з основнимн країнами-міграційнимн партнерами }\end{array}$ \\
\hline$\rightarrow$ & $\begin{array}{l}\text { Стратегічний підхід до управління процесами імміграції: актнвне вжнвання } \\
\text { заходів, спрямованих на протидію розповсюдження нелегальної міграції й } \\
\text { кримінальннх дій, пов'язаних } 3 \text { переміщення людей. Щодо внутрішньої міграції- } \\
\text { усунення інституціональннх бар'єрів для прнскорення економічних міграцій і } \\
\text { перерозподілу трудовнх ресурсів по тернторії країни }\end{array}$ \\
\hline
\end{tabular}

\section{Рис. 1. Механізми регулювання міграційних процесів у відповідності до міжнародних стандартів та вимог Європейського Союзу}

Підсумовуючи зазначене вище, необхідно посилити роботу державних органів влади в напрямі вдосконалення міграційної політики: 1) чітко визначити стратегію і тактику у формуванні та реалізації міграційної політики органами державної влади, стратегію підготовки фахівців у цій галузі; 2) довершити формування нормативно-правової бази в сфері міграційної політики, створити правові і соціально-економічні засади регулювання трудової міграції; 3) розробити ефективну, скореговану концепцію міграційної політики держави, забезпечити іï впровадження та функціонування; 4) скоротити виїзд 3 України та сприяти поверненню мігрантів, які виїхали раніше; мобілізації трудового потенціалу держави шляхом стимулювання імміграції 3-за кордону; забезпечення умов для результативного використання праці тимчасових працівників 3-за кордону в інтересах української економіки; захист прав та свобод мігрантів, у т.ч. вимушених, та запобігання незаконній міграції; 5) поглибити наукові дослідження у сфері міграції та удоско314 
налення міграційної статистики; 6) посилити розвиток міжнародного співробітництва, співпрацю з громадянським суспільством, асоціаціями мігрантів в Україні і за кордоном $[1,6]$.

Незважаючи на значний прогрес у розвитку, формуванні та реалізації міграційної політики України, що відбувається останніми роками, чіткого, цілеспрямованого, всебічного регулювання міграційних процесів все ще недостатньо. Реалізація міграційної політики держави, що відповідає сучасним вимогам, набуває стратегічного значення і повинна: формуватися прозоро; мати комплексний характер; базуватися на поглибленому розумінні міграційної ситуації в державі; конкретній та достовірній міграційній статистиці, наукових дослідженнях; реалізовуватися на основі чітко скоординованій роботі різних урядових структур, місцевої влади, соціальних партнерів, неурядових організацій та характеризуватися єдністю поглядів на всі міграційні потоки та стадії міграційного процесу, а також включенням міграційних питань в усі інші сфери діяльності держави. Від успішного забезпечення та вирішення якої залежатиме подальший політичний, соціально-економічний та культурний розвиток нашої держави.

\section{Література:}

1. Міграційна політика сучасної держави: сутність та шляхи впровадження URL: http://dspace.univer.kharkov.ua/handle/1234567 89/2449.pdf

2. Боднар С. Міграційна політика України та ії виклики. // Правові виклики сучасності: міжнародна міграція в умова глобалізаuіï: Матеріали I Міжнар. наук.-практ. онлайн конф. (Чернівці, 23 жовтня 2020 р.). - Чернівці : Чернівец. нац. ун-т ім. Ю. Федьковича, 2020. C. $71-73$

3. Супруновський А.I. Проблеми формування міграційної політики України // Актуальні проблеми держави $і$ права. 2010. C. 401-406 URL: http://www.apdp.in.ua/v52/66.pdf

4. Іншин М. Про основні засади державної міграційної політики України // Правові виклики сучасності: міжнародна міграція в умова глобалізації: Матеріали I Міжнар. наук.-практ. онлайн конф. (Чернівці, 23 жовтня 2020 р.). - Чернівці : Чернівец. нац. ун-т ім. Ю. Федьковича, 2020. C. $61-63$

5. Завора Л.І., Власенко В.А. Проблеми міграційної політики України та шляхи ї вирішення URL: http://dspace.puet.edu.ua/bitstream/ 123456789/9862/1/\%D0\%97\%D0\%B0\%D0\%B2\%D0\%BE\%D1\%80\%D0 $\%$ B0.pdf

6. Малиновська О. Міграційна політика в Україні: формування, зміст, відповідність сучасним вимогам. Аналітична записка M/1, 2014 URL: http://www.ier.com.ua/files/publications/Policy_Briefing_Series/PB_ 01_migration_2013_ukr.pdf 